\title{
STUDI KASUS PENERAPAN KURIKULUM TINGKAT SATUAN PENDIDIKAN (KTSP) INTEGRATIF DI SMP IBRAHIMY 2 SUKOREJO SITUBONDO
}

\author{
Oleh: \\ Rahwan \\ Universitas Ibrahimy Situbondo \\ ach.rahwan@gmail.com
}

\begin{abstract}
:
The curriculum is the intention and hope as outlined in the form of an education plan or program to be carried out by the teacher in the school. Curriculum content is scientific knowledge, including activities and learning experiences arranged according to the level of student development. One of the efforts of curriculum development is by integrating integrative KTSP curriculum. Recently, the integrated integrative KTSP curriculum has become the excellent in each education unit. One of the educational units that applied was SMP 2 Ibrahimy, Sukorejo Situbondo. As an educational unit structurally under the auspices of the National Education Board and culturally under the auspices of the Salafiyah Syafi'iyah Sukorejo Situbondo Islamic Boarding School, SMP 2 Ibrahimy is required to be able to implement KTSP which is integrated between the pesantren curriculum and the national standard curriculum. From this background, SMP Ibrahimy 2 integrated KTSP (general and pesantren) since (2003) until now (2012). To find out the three main points, this research was arranged in 3 (three) formulation of the problem; how is the preparation, implementation, and indication in the success of integrating integrative KTSP in SMP 2 Ibrahimy?
\end{abstract}

Keyword: Integration, KTSP, Ibrahimy 2 Middle School, Islamic Boarding School

\section{A. Pendahuluan}

Pendidikan seharusnya dipandang sebagai sebuah sistem. Ini merupakan konsep yang sulit dipahami oleh profesional pendidikan. Umumnya, orang yang bekerja dalam bidang pendidikan memulai perbaikan sistem tanpa mengembangkan pemahamannya. Realitanya, manusia dalam segala hal selalu berusaha mencari efektivitas dan efisiensi kerja dengan jalan memilih dan menggunakan suatu cara yang dianggap terbaik untuk mencapai tujuannya. Demikian pula pada 
lembaga sekolah, pengelola dan pendidik akan selalu berusaha memilih metode pengajaran dan kurikulum yang paling tepat, yang dipandang lebih efektif dibandingkan dengan metode atau kurikulum lainnya, sehingga kecakapan dan pengetahuan yang ditransformasikan oleh guru itu benar-benar menjadi milik murid. ${ }^{1}$

Dalam setiap proses pembelajaran akan selalu ada tiga (3) komponen penting yang saling terkait satu sama lain. Tiga komponen penting itu adalah; kurikulum, yaitu berisi materi yang akan diajarkan; proses, yaitu bagaimana materi diajarkan dan produk, merupakan hasil dari proses pembelajaran. Ketiga aspek ini sama pentingnya, karena merupakan satu kesatuan yang membentuk lingkungan pembelajaran. Satu kesenjangan yang selama ini dirasakan dan dialami adalah kurangnya pendekatan yang benar dan efektif dalam menjalankan proses pembelajaran. Selama ini pendidikan lebih terfokus pada materi dan hasil pembelajaran. Namun yang sering terlupakan adalah satu proses tersendiri untuk bisa menjembatani antara kurikulum dan hasil pembelajaran. Yang terjadi selama ini adalah apabila guru mengajar, maka diasumsikan pada saat itu murid akan belajar dan paham. Satu asumsi yang salah, namun jarang sekali ada orang yang mempertanyakan asumsi dasar tersebut. ${ }^{2}$

Pada pendidikan formal, kurikulum sangat diharapkan mampu meningkatkan prestasi belajar siswa. Prestasi belajar berarti suatu keberhasilan yang diperoleh setelah memperoleh didikan atau latihan tertentu. ${ }^{3}$ Menurut Barelson dan Steiner; Learning: change in behavior result from previous behavior in similar situation. Belajar merupakan suatu perubahan tingkah laku yang mengacu kepada akibat-akibat yang ditimbulkan oleh pengalaman terhadap tingkah laku berikutnya. ${ }^{4}$

Pelaksanaan pendidikan dibagi atau diatur dalam tahapan/tingkatan pelaksanaan pendidikan. Tingkat pendidikan dalam sistem pendidikan nasional terdiri atas tingkat pendidikan dasar, pendidikan menengah dan pendidikan tinggi. Setiap tingkatan mempunyai tujuan tersendiri yang merupakan penjabaran dari tujuan umum

\footnotetext{
${ }^{1}$ Suryobroto, Proses Belajar-Mengajar di Sekolah, (Jakarta: Rineka Cipta, 1997), 148.

2 Adi W. Gunawan, Genius Learning Strategy, (Jakarta: PT. Gramedia Pustaka Utama, 2004), 1.

${ }^{3}$ J. J. Pasaribu dan B. Simanjuntak, Proses Belajar Mengajar, (Bandung: Tarsito, 1980), 115.

${ }^{4}$ Bernand Berelson dan Carry Steiner, Human Behavior an Interview of Scientific Findings, (New York Brase \& Word Inc, 1964), 135.
}

198 JURNAL LISAN AL-HAL 
pendidikan institusional. Untuk mencapai tujuan institusional diperlukan alat dan sarana, di antaranya adalah kurikulum untuk setiap lembaga pendidikan. Kurikulum inilah yang menjadi alat untuk membina dan mengembangkan siswa menjadi manusia yang berilmu dan berkemampuan intelektual tinggi, bermoral sebagai pedoman hidupnya serta mengamalkan ilmunya untuk kepentingan orang lain.

Kurikulum adalah niat dan harapan yang dituangkan dalam bentuk rencana atau program pendidikan untuk dilaksanakan oleh guru di sekolah. Isi kurikulum adalah pengetahuan ilmiah, termasuk kegiatan dan pengalaman belajar, yang disusun sesuai dengan taraf perkembangan siswa. Kurikulum akan mempunyai arti dan fungsi untuk mengubah siswa apabila dilaksanakan dan ditransformasikan oleh guru kepada siswa dalam suatu kegiatan belajar mengajar. Dengan kata lain bahwa proses belajar mengajar adalah operasionalisasi dari kurikulum. ${ }^{5}$

Konsep kurikulum berkembang sejalan dengan perkembangan teori dan praktik pendidikan, juga bervariasi dengan aliran atau teori pendidikan yang dianutnya. Ada tiga (3) konsep tentang kurikulum; pertama, kurikulum dipandang sebagai substansi, kedua, kurikulum sebagai sistem dan ketiga, kurikulum dipandang sebagai bidang studi. ${ }^{6}$

Menurut pandangan lama, kurikulum merupakan kumpulan mata pelajaran yang harus disampaikan guru atau dipelajari oleh siswa. ${ }^{7}$ Dalam lingkungan atau hubungan tertentu pandangan ini masih dipakai sampai sekarang, sebagaimana yang diungkapkan oleh al-Shaybani sebagaimana dikutip oleh Hasan Langgulung mengatakan bahwa kurikulum adalah sejumlah pengalaman pendidikan, kebudayaan, sosial, olahraga dan kesenian yang disediakan oleh sekolah bagi murid-murid di dalam dan di luar sekolah dengan maksud menolongnya untuk berkembang menyeluruh untuk merubah tingkah laku mereka sesuai dengan tujuan-

5 Nana Sudjana, Pembinaan dan Pengembangan Kurikulum di Sekolah, (Jakarta: Sinar Baru Algensindo, 2005), 3.

6 Nana Syaodih Sukmadinata, Pengembangan Kurikulum Teori dan Praktik, (Bandung: Remaja Rosdakarya, 2000), 27.

7 Dalam masalah ini Mauritz Johson mengajukan keberatan mengenai konsep kurikulum tersebut. Menurutnya, pengalaman hanya akan muncul apabila terjadi interaksi antara siswa dengan lingkungannya. Interaksi seperti itu bukanlah kurikulum, tetapi pengajaran. Kurikulum hanya menggambarkan atau mengantisipasi hasil dari pengajaran. Semua yang berkenaan dengan perencanaan dan pelaksanaan, seperti perencanaan isi, kegiatan belajar-mengajar, evaluasi, termasuk pengajaran. Sedangkan kurikulum hanya berkenaan dengan hasil-hasil belajar yang diharapkan dicapai oleh siswa. Lihat: Mauritz Johson, Internationality in Education, (New York: Center for Curriculum Research and Services, 1967), 130. 
tujuan pendidikan. ${ }^{8}$

Terlepas dari pro kontra mengenai pengertian kurikulum di atas, dapat ditarik suatu benang merah mengenai kurikulum. Kurikulum adalah seperangkat aturan yang harus dilalui oleh murid, pengalaman, kegiatan dan pengetahuan murid di bawah bimbingan dan tanggungjawab sekolah atau guru untuk mencapai suatu jenjang tertentu. Kurikulum juga merupakan suatu rencana pendidikan, pedoman dan pegangan tentang jenis, lingkup dan urutan isi serta proses pendidikan.

Kurikulum memegang peranan yang sangat penting untuk mencapai keberhasilan suatu pendidikan. Keberhasilan pendidikan dapat dicapai apabila salah satu dari perangkatnya yakni perencanaan dan pelaksanaan kurikulum yang matang. Melihat realita yang ada mengenai kemerosotan pendidikan di Indonesia sudah terasakan selama bertahuntahun, dan untuk ke sekian kalinya kurikulum dituding sebagai penyebabnya. Hal ini tercermin dengan keberadaan kurikulum yang kurang terencana dengan matang dan upaya selalu mengubah kebijakan kurikulum, mulai kurikulum 1974 sampai dengan digantinya kurikulum 2004 (KBK) dengan kurikulum 2006 (KTSP).

Nasanius berpendapat bahwa kemerosotan pendidikan bukan diakibatkan oleh kurikulum, tetapi oleh kurangnya kemampuan profesionalisme guru dan keengganan belajar siswa. Profesionalisme menekankan kepada penguasaan ilmu pengetahuan atau kemampuan manajemen beserta struktur penerapannya. Profesionalisme bukan sekadar pengetahuan teknologi dan manajemen tetapi lebih merupakan sikap. Pengembangan profesionalisme lebih dari seorang teknisi bukan hanya memiliki keterampilan yang tinggi tetapi juga memiliki suatu tingkah laku yang dipersyaratkan. ${ }^{9}$

Kurikulum Tingkat Satuan Pendidikan (KTSP) diberlakukan mulai tahun ajaran 2006/2007. Berbeda dengan beberapa kurikulum sebelumnya, KTSP disusun oleh satuan pendidikan masing-masing.

8 Hasan Langgulung, Manusia dan Pendidikan: Suatu Analisa Psikologik dan Pendidikan, (Jakarta: Pustaka al-Husna, 1989), 145. Selanjutnya Langgulung berpendapat bahwa kurikulum mempunyai empat unsur atau aspek, antara lain: 1) tujuan-tujuan yang ingin dicapai, 2) pengetahuan (knowledge), data-data, informasi, aktivitas, pengalaman dari mana terbentuk kurikulum tersebut. Bagian inilah yang biasa disebut dengan mata pelajaran, 3) metode dan cara-cara mengajar yang dipakai oleh guru-guru untuk mengajar dan mendorong murid-murid belajar dan membawa ke arah yang dikehendaki oleh kurikulum, 4) metode dan cara penilaian dalam kurikulum seperti ujian triwulan, semester dan lain-lain.

9 Amhasan, "Pengembangan Profesionalisme", http://artikel.US/amhasan.html (20 Maret, 2007).

$200 \mid$ JURNAL LISAN AL-HAL 
Pemerintah dalam hal ini Depdiknas hanya memberikan rambu-rambu penyusunan atau pengembangannya. Rambu-rambu yang berlandaskan piranti hukum mulai dari Undang-Undang Republik Indonesia Nomor 20 tahun 2003 (UU 20/2003) tentang Sistem Pendidikan Nasional dan PP RI Nomor 19 tahun 2005 tentang Standar Nasional dan Pendidikan mengamanatkan kurikulum KTSP (Kurikulum Tingkat Satuan Pendidikan) pada jenjang Pendidikan Dasar dan Menengah yang disusun oleh satuan pendidikan dengan mengacu kepada SI (Standar Isi) dan SKL (Standar Kompetensi Lulusan) serta berpedoman pada panduan yang disusun oleh Badan Standar Nasional Pendidikan (BSNP). Selain itu, penyusunan KTSP juga harus mengikuti ketentuan lain yang menyangkut kurikulum dalam UU 20/2003 dan PP 19/2005.10

Peraturan Pemerintah Republik Indonesia Nomor 19 Tahun 2005 tentang Standar Nasional Pendidikan, Peraturan Menteri Pendidikan Nasional Nomor 22 Tahun 2006 tentang Standar Isi untuk Satuan Pendidikan Dasar dan Menengah, Peraturan Menteri Pendidikan Nasional Nomor 23 Tahun 2006 tentang Standar Kompetensi Lulusan untuk Satuan Pendidikan Dasar dan Menengah, Peraturan Menteri Pendidikan Nasional Nomor 24 Tahun 2006 tentang Pelaksanaan Peraturan Menteri Pendidikan Nasional Nomor 22 Tahun 2006 dan Nomor 23 Tahun 2006, satuan pendidikan (SD/MI, SMP/MTs, SMA/MA) diharapkan bisa mengembangkan KTSP sebagai dasar untuk merencanakan, melaksanakan dan menilai pembelajaran bagi siswa. ${ }^{11}$

KTSP yang merupakan penyempurnaan dari kurikulum 2004 (KBK) adalah kurikulum operasional disusun dan dilaksanakan oleh masing-masing satuan pendidikan/sekolah. Departemen Pendidikan Nasional mengharapkan paling lambat tahun pelajaran 2009/2010, semua satuan pendidikan telah melaksanakan KTSP, baik yang swasta maupun negeri, mulai tingkat dasar hingga tingkat atas.

SMP Ibrahimy 2 Sukorejo Situbondo sebagai satuan pendidikan rintisan sekolah level internasional telah memberlakukan kurikulum KTSP sejak kurikulum ini telah ditetapkan. Dalam arti, SMP Ibrahimy 2 telah memiliki kurikulum buatan sendiri dan dianggap telah mengacu peraturan pemerintah dan peraturan-peraturan menteri di atas. Dengan background yang diwarnai kepesantrenan, SMP Ibrahimy 2 mengawinkan (integrasi)

10 BSNP, Panduan Penyusunan KTSP Jenjang Pendidikan Dasar dan Menengah, (tt: tp., 2006), 3 .

11 Masnur Muslich, KTSP Dasar Pemahaman dan Pengembangannya, (Jakarta: Bumi Aksara, 2007), 5.

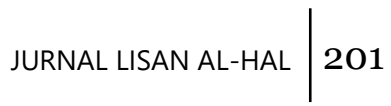


KTSP berdasarkan Peraturan Pemerintah dengan KTSP berbasis nuansa pesantren. Hal ini dilakukan karena terinspirasi adanya indikasi melemahnya kepercayaan masyarakat terhadap sekolah-sekolah umum, karena hanya mencetak lulusan yang berbekal IPTEK (ilmu pengetahuan dan teknologi) tanpa diimbangi dengan IMTAQ (iman dan takwa), SMP Ibrahimy 2 Sukorejo Situbondo sebagai salah satu lembaga pendidikan formal berhasil memadukan kurikulum nasional (KTSP) dengan kurikulum pesantren yang berbekal IPTEK dan IMTAQ. Sebuah tantangan dari sebuah lembaga yang bernaung di bawah pendidikan nasional, tetapi berani menawarkan beberapa kurikulum dan program pesantren sebagai bekal bagi para siswanya untuk mempunyai life skill dalam bidang agama, di samping pengetahuan umum yang memadai.

Namun dalam perjalanannya, ada beberapa persoalan yang perlu dicermati untuk mengevaluasi apakah KTSP sudah benar-benar connected dengan peraturan pemerintah atau justru malah sebaliknya. Salah satu dari beberapa persoalan tersebut yaitu bagaimana SMP Ibrahimy 2 Sukorejo Situbondo menyusun struktur dalam menerapkan dan mengintegrasikan kurikulum standar nasional (KTSP) dengan kurikulum pesantren.

Sebagian besar para siswanya adalah masyarakat sekitar pesantren. Sementara itu, SMP Ibrahimy 2 Sukorejo Situbondo adalah lembaga pendidikan yang menginduk di bawah payung pendidikan nasional, namun dalam hal ini masih mempertahankan tradisi pesantren. Salah satu indikasinya adalah masih dimasukkannya beberapa mata pelajaran pesantren dalam jam pelajaran resmi dan waktu yang khusus. Yang lebih menarik lagi adalah bahwa mata pelajaran pesantren menjadi salah satu standar wajib pelulusan siswa. Indikasi ini tentu menjadi nilai tersendiri bagi SMP Ibrahimy 2 Sukorejo Situbondo berusaha memadukan kurikulum nasional dan pesantren yang bertujuan untuk meningkatkan kompetensi life skill siswa dalam bidang umum dan agama. Oleh karena itu, dengan segala kemampuan dan fasilitas yang ada SMP Ibrahimy 2 Sukorejo Situbondo mencoba memberi corak dan nuansa lain model pendidikan terpadu.

Penerapan kurikulum dan pembelajaran yang dilakukan oleh SMP Ibrahimy 2 Sukorejo Situbondo selama ini masih jarang sekali dilaksanakan oleh lembaga-lembaga pendidikan formal di lingkungan Pesantren dan sekitarnya. Terutama sekali yang menjadi menarik dalam kajian penelitian ini adalah lembaga SMP Ibrahimy 2 Sukorejo Situbondo yang bernaung di bawah Depdiknas yang mampu menerapkan kurikulum pesantren sebagai salah satu program unggulannya. Hal ini dapat 
dijadikan masukan dan rujukan untuk mengembangkan lembaga-lembaga pendidikan Islam lainnya menuju prospek pendidikan yang lebih menekankan kemampuan skill dan kompetensi serta yang berwawasan islami.

SMP Ibrahimy 2 Sukorejo Situbondo adalah lembaga sekolah umum yang masih terbilang sangat muda, namun dalam perkembangannya telah menjadi salah satu contoh lembaga pendidikan lain mengenai model pengembangan lembaga pendidikan yang inovatif. Baik pengembangan manajemen lembaga, model pembelajaran dan inovasi kurikulum. Oleh karena itu, alasan utama pemilihan fokus bahasan di atas, karena penulis ingin mengetahui sejauh mana kurikulum nasional dan kurikulum pesantren mampu diintegrasikan dan diterapkan di sekolah tersebut. Penulis berusaha untuk melakukan penelitian dengan mengambil judul penelitian "Studi Kasus Penerapan Kurikulum Tingkat Satuan Pendidikan (KTSP) Integratif di SMP Ibrahimy 2 Sukorejo Situbondo".

Jenis penelitian ini merupakan penelitian kualitatif yang dalam pengumpulan datanya dilakukan dengan cara observasi, wawancara, dan dukumentasi, serta kajian pustaka. Data-data yang diperoleh dianalisis secara mengalir yang mencorak tiga proses: reduksi data, sajian data dan penarikan kesimpulan.

Dengan teknik pengumpulan dan analis data tersebut, penelitian ini menyimpulkan bahwa: (1) Model penyusunan KTSP dengan kurikulum pesantren di SMP Ibrahimy 2 Sukorejo adalah dengan cara memasukkan materi-materi keagamaan yang merupakan kewajiban dari pesantren. Materi-materi tersebut yaitu: Fiqh, Aqidah Akhlak, Nahwu Sharraf, Alquran, Bahasa Arab; (2) Dalam pengimplementasiannya, kurikulum nasional tetap diadopsi dan dilaksanakan secara keseluruhan sesuai dengan aturan dan petunjuknya. Struktur integrasi kurikulum ini termasuk dari pengembangan kurikulum lembaga sehingga tidak menyalahi aturan yang ditetapkan oleh Sistem Pendidikan Nasional. (3) Keberhasilan implementasi integrasi Kurikulum Tingkat Satuan Pendidikan (KTSP) di SMP Ibrahimy 2 Sukorejo dapat dilihat dari kinerja guru, ketuntasan belajar, ketuntasan materi pelajaran, pencapaian prestasi akademik siswa, dan prestasi non-akademik. 


\section{B. Pembahasan}

1. Struktur Integrasi Kurikulum Tingkat Satuan Pendidikan (KTSP) dengan Kurikulum Pesantren di SMP Ibrahimy 2 Sukorejo Situbondo

Berdasarkan temuan penelitian ini, struktur penyusunan KTSP dengan mengintegrasikan kurikulum pesantren dan nasional di SMP Ibrahimy 2 Sukorejo adalah dengan cara memasukkan materi-materi keagamaan yang merupakan kewajiban dari pesantren. Dengan demikian, struktur penyusunan kurikulum secara terintegrasi berawal dari amanah pesantren yang secara kultural memang berada di atas SMP Ibrahimy 2 . Amanah dari pesantren ini dijadikan pijakan untuk mengintegrasikan kurikulum. Selain itu, pihak sekolah SMP Ibrahimy 2 juga melihat potensi lingkungan sekitar yang bernuansa keagamaan. Hal ini mengindikasikan bahwa integrasi kurikulum SMP Ibrahimy 2 sudah menjalankan prinsipprinsip pengembangan KTSP, yaitu prinsip beragam dan terpadu; prinsip relevan dengan kebutuhan hidup.

Pihak-pihak yang terlibat dalam penyusunan kurikulum agak berbeda dengan yang biasa dilakukan dengan sekolah-sekolah lainnya. Di SMP Ibrahimy 2, pihak-pihak yang terlibat dalam penyusunan kurikulum integrasinya adalah kepala sekolah, dewan guru, bagian kurikulum, konselor, dan bagian kurikulum dari pihak pesantren, serta komite sekolah. Pelibatan bagian kurikulum pesantren inilah yang membedakan integrasi kurikulum di SMP Ibrahimy 2 dengan sekolah lainnya. Menurut hasil wawancara, hal ini dilakukan karena dengan melibatkan Bag. Kurikulum pesantren maka hasilnya akan semakin efektif dan efisien.

Selanjutnya, penyusunan KTSP-nya, SMP Ibrahimy 2 memasukkan materi-materi kurikulum pesantren dalam kurikulumnya. Materi-materi tersebut yaitu: Fiqh, Aqidah Akhlak, Nahwu Sharraf, Alquran, Bahasa Arab. Materi ini, sekalipun hanya materi yang terintegrasikan, tapi juga dimasukkan ke jam-jam aktif sekolah yang berdurasi full day $06.45 \mathrm{~s} / \mathrm{d}$ 15.15). Jadi, materi-materi tersebut bukanlah materi ekstrakurikuler, melainkan juga materi wajib di SMP Ibrahimy 2.

Demikianlah deskripsi penyusunan KTSP di SMP Ibrahimy 2. Jika dikaji dari aspek jenis kurikulumnya maka pola penyusunan kurikulumnya termasuk kategori integrated curriculum (kurikulum terpadu). Sedangkan pola integrasi kurikulumnya termasuk pola yang keempat dari pola-pola yang ada di integrated curriculum. Pola keempat

\footnotetext{
$204 \mid$ JURNAL LISAN AL-HAL
} 
tersebut yaitu pola sekolah umum dan pesantren. ${ }^{12}$ Menurut Hendyat Soetopo dan Wasty Soemanto, ciri-ciri pola ini yaitu pendidikan agama diberikan sebagai non-kurikuler atau bahkan dimasukkan sebagai kurikulum sekolah sebagai muatan lokal. Program ini sepenuhnya mengintegrasikan sekolah umum dengan sistem pendidikan pesantren yang bercorak tradisional. ${ }^{13}$

Dilihat dari sisi pemilihan isinya, struktur integrasi kurikulum yang dilakukan oleh SMP Ibrahimy 2 adalah sesuai dengan standart pemilihan isi dari para pakar pendidikan. Menurut Hamid Syarif,14 Standart pemilihan isi kurikulum setidaknya memenuhi 3 syarat: (1) Bahan kurikulum harus sesuai; (2) Bahan kurikulum harus mencerminkan kehidupan sosiokultural; dan (3) Bahan kurikulum harus dapat mencapai tujuan yang di dalamnya mengandung aspek intelektual, emosional, sosial, dan moral keagamaan. ${ }^{15}$ Dari ketiga syarat tersebut, struktur pengintegrasian SMP Ibrahimy 2 yang di dalamnya memasukkan materi Fiqh, Aqidah, Akhlak, Alquran dan Tata Bahasa Arab memang sudah memenuhi 3 kriteria tersebut. Sebab, dilihat dari faktor yang mempengaruhi integrasi kurikulumnya, memang didasarkan pada lingkungan sekitar SMP Ibrahimy 2 yang memungkinkan pengintegrasian tersebut. Sosiokultural dari lingkungan SMP Ibrahimy 2 memang menginginkan kompetensi siswa-siswinya cakap dalam ilmu umum dan agama secara seimbang.

Dari aspek tujuan, SMP Ibrahimy 2 dalam struktur integrasi kurikulumnya juga bertujuan mementingkan aspek intelektual, emosional, sosial, dan moral keagamaan. Sebab, tujuan dari integrasi kurikulum SMP Ibrahimy 2 adalah selain mendukung dan melengkapi materi PAI, juga untuk menyeimbangkan antara ilmu umum dan ilmu keagamaan. Dengan demikian, aspek intelektual, emosional, sosial, dan moral keagamaan sudah terakomodir semuanya.

Untuk lebih memperjelas pembahasan pada sub bab ini, berikut ini bagan struktur integrasi kurikulum pesantren dilihat dari kajian teori.

12 Luqman Hakim, Kapita Selekta Pondok Pesantren, Tradisi Pendidikan Pesantren (Jakarta: Depag RI, 2002), 41.

${ }^{13}$ Hendyat Soetopo dan Wasty Soemanto, Pembinaan dan Pengembangan Kurikulum, (Jakarta: Bumi Aksara, 1993), 33.

${ }^{14}$ A. Hamid Syarif, Pengembangan Kurikulum, (Surabaya: PT Bina Ilmu, 1996), 51.

15 Mulyasa, Kurikulum, (Jakarta: Raja Grafindo Persada, 2008), 20-21., Kunandar, Guru Profesional, (Jakarta: Raja Grafindo Persada, 2007), 119. 


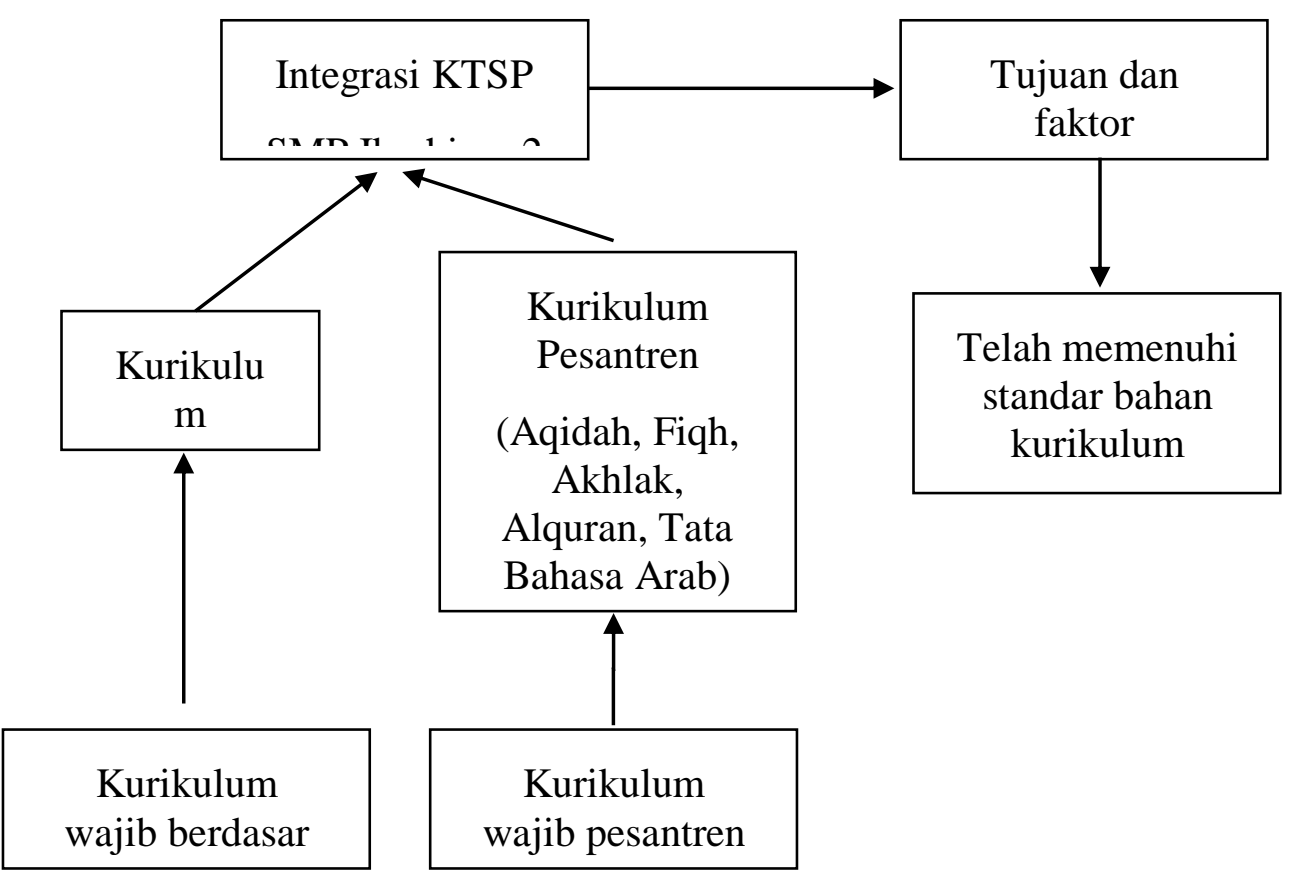

Bagan 5.1: Struktur Integrasi KTSP dengan Kurikulum Pesantren di SMP Ibrahimy 2 Sukorejo Situbondo

\section{Implementasi Integrasi Kurikulum Tingkat Satuan Pendidikan (KTSP) dengan Kurikulum Pesantren di SMP Ibrahimy 2 Sukorejo Situbondo}

Dalam pengimplementasiannya, kurikulum nasional tetap diadopsi dan dilaksanakan secara keseluruhan sesuai dengan aturan dan petunjuknya. Sedangkan kurikulum pesantren dimasukkan dalam kurikulum lokal dengan cara menambahkan jumlah alokasi jam pelajaran. Struktur integrasi kurikulum ini termasuk dari pengembangan kurikulum lembaga sehingga tidak menyalahi aturan yang ditetapkan oleh Sistem Pendidikan Nasional.

Dalam teknik pelaksanaannya, Untuk durasi waktu yang disediakan pada MAPEL Fiqh, Aqidah, Akhlak, Alquran adalah 2 jam per minggu dengan pengajar yang sama dengan pengajar PAI yang notabene merupakan kurikulum nasional. Program BMQ (Bimbingan Membaca Alquran) juga diterapkan dalam pendalaman materi Alquran dan jamnya dilaksanakan di jam-jam ekstrakurikuler. Pelaksanaan ini tidak sampai mengganggu jam pelajaran MAPEL lainnya yang merupakan MAPEL wajib dari kurikulum nasional. Sebab, ada tambahan waktu pelajaran dalam pelaksanaannya, yaitu dengan menerapkan full day school $(06.45 \mathrm{~s} / \mathrm{d}$ 
15.15). Dengan demikian, pengalokasian waktu untuk MAPEL tambahan tersebut sudah sesuai dengan pengaturan beban belajar yang tertera dalam struktur dan muatan KTSP. Dalam pengaturan jam pembelajaran, disebutkan bahwa tambahan jam untuk MAPEL diperbolehkan senyampang sesuai dengan kebutuhan peserta didik dan dengan mempertimbangkan MAPEL lainnya. Dalam arti, tambahan MAPEL tidak boleh sampai mengganggu jam pelajaran lainnya.

Program BMQ yang merupakan pendukung MAPEL Alquran juga telah memenuhi standar pengaturan belajar. Sebab, khusus untuk BMQ dilakukan di jam-jam ekstrakurikuler. Selanjutnya Untuk durasi waktu yang disediakan pada MAPEL Tata Bahasa Arab (Nahwu dan Sharraf) adalah 4 jam per minggu dengan pengajar lain. Untuk menunjang MAPEL ini, diadakan program BMK (Bimbingan Membaca Kitab). Alokasi 4 jam untuk MAPEL Tata Bahasa Arab memang disediakan lebih, sebab MAPEL ini merupakan materi wajib dikuasai sebelum melaksanakan UN. Bahkan, di waktu ekstra pun dilakukan BMK untuk penunjangan penguasaan materi. Implementasi ini juga sudah sesuai dengan standar pengaturan beban belajar yang menyatakan bahwa maksimal alokasi waktu untuk MAPEL tambahan adalah 4 jam per minggu. Sedangkan untuk BMK-nya dilakukan di jam-jam ekstra yang tidak mengganggu MAPEL lainnya, sebab hanya dialokasikan 2 jam pe minggunya.

Dari sisi kenaikan kelas dan kelulusannya, ada hal yang menarik dalam KTSP di SMP Ibrahimy 2. Berbeda dengan sekolah pada biasanya, SMP Ibrahimy 2 menekankan agar MAPEL Tata Bahasa Arab dan Alquran harus benar-benar dipahami secara mendalam oleh para siswa-siswi, sebab sebelum mengikuti ujian UN, diwajibkan lulus ujian baca kitab dan lulul ujian baca Alquran. Bila dilihat dari aspek Peraturan Pemerintah yang berkenaan dengan standart kelulusan maka hal ini tentu tidak tertera dalam PP 19/2005 pasal 72 ayat 1. Pada PP ini hanya tertera 4 ketentuan kelulusan yang harus dipenuhi oleh siswa-siswi, yaitu: (1) Menyelesaikan seluruh program pembelajaran; (2) Memperoleh nilai minimal baik pada penilaian akhir untuk seluruh mata pelajaran kelompok mata pelajaran agama dan akhlak mulia, kelompok kewarganegaraan dan kepribadian, kelompok mata pelajaran estetika, dan kelompok mata pelajaran jasmani, olahraga, dan kesehatan; (3) Lulus ujian sekolah/madrasah untuk kelompok mata pelajaran ilmu pengetahuan dan teknologi; dan (4) Lulus Ujian Nasional.

Dari keempat standar kelulusan tersebut tidak disebutkan bahwa siswa harus lulus ujian yang secara lokal diadakan oleh Satuan Pendidikan. Hal ini menunjukkan bahwa pelaksanaan ujian kompetensi baca kitab dan 
baca Alquran oleh SMP Ibrahimy 2 terlihat kurang sesuai dengan standart kelulusan nasional. Namun demikian, hal ini bukan berati SMP Ibrahimy 2 tidak mempertimbangkan standar kelulusan nasional. Hal ini dilakukan dalam rangka mengejawantahkan pengintegrasian kurikulum pesantren dan nasional. Dalam arti, sebagai dampak integrasi kurikulum maka ujian baca kitab dan Alquran memang wajib dilakukan sebab itu merupakan amanah pesantren.

Kewajiban ujian kitab dan Alquran ini merupakan salah satu keseriusan SMP Ibrahimy 2 dalam penyelenggaraan MAPEL tambahan. Dengan begitu, MAPEL tambahan bukan hanya sebagai formalitas saja, melainkan juga wajib dilaksanakan sampai tuntas untuk mencapai tujuan umum: "Penyeimbangan IMTAQ dan IPTEK". Selain itu, ketentuan ini juga merupakan tuntutan dari lingkungan sekitar yang menginginkan siswasiswi cakap membaca kitab dan fasih dalam melafalkan Alquran. Penjelasannya, ujian wajib kitab diberlakukan karena untuk mendukung pendalaman materi keagamaan, Fiqh, Akhlak, dam Aqidah. Dengan penguasaan pada pembacaan kitab maka secara otomatis siswa-siswi akan mudah dalam memahami materi-materi tersebut. Sedangkan ujian wajib Alquran bertujuan untuk mendukung materi Alquran yang juga merupakan materi PAI dan materi integrasi.

Dengan demikian, secara substantif program ujian wajib kitab dan Alquran ini juga relevan dengan standar kelulusan nasional, sebab di standar kedua dinyatakan bahwa siswa-siswi wajib memperoleh nilai minimal baik pada penilaian akhir untuk mata pelajaran kelompok mata pelajaran agama dan akhlak mulia.

Dari sisi kelengkapan perangkat pembelajaran MAPEL tambahan, Tiap-tiap MAPEL tambahan sudah dilengkapi dengan SK-KD dan RPP dari masing-masing MAPEL. Bahkan, pada materi Tata Bahasa Arab (Nahwu \& Sharraf) telah ada buku panduannya yang diteritkan oleh SMP Ibrahimy 2 sendiri. Hal ini adalah langkah kreatif SMP Ibrahimy 2. Penerapan struktur ini sesuai dengan yang diamanatkan implementasi Undang-Undang Nomor 20 tahun 2003 tentang Sistem Pendidikan Nasional yang dijabarkan ke dalam sejumlah peraturan antara lain Peraturan Pemerintah Nomor 19 tahun 2005 tentang Standar Nasional Pendidikan. Peraturan Pemerintah ini memberikan arahan tentang perlunya disusun dan dilaksanakan beberapa standar nasional pendidikan dan tenaga kependidikan, standar sarana dan prasarana, standar pengelolaan, standar pembiayaan dan standar penilaian pendidikan.

Secara keseluruhan, SMP Ibrahimy 2 telah memenuhi Standar Nasional Pendidikan (SNP). SNP digunakan sebagai acuan pengembangan 
kurikulum, tenaga kependidikan, sarana dan prasarana, pengelolaan dan pembiayaan. Penyusunan Kurikulum Tingkat Satuan Pendidikan (KTSP) selain mengacu pada SNP juga berpedoman pada Panduan Penyusunan Kurikulum Tingkat Satuan Pendidikan yang diterbitkan oleh BSNP.

Berikut ini adalah kriteria-kriteria kelayakan sekolah dalam pengembangan kurikulum antara lain yang telah diimplementasikan di SMP Ibrahimy 2, yaitu: Pertama, Adanya sumber daya, potensi dan kebutuhan daerah yang mencakup aspek ekonomi, budaya, bahasa, teknologi informasi dan komunikasi (TIK), ekologi dan lain-lain yang dapat dikembangkan sebagai program keunggulan lokal. Keunggulan daerah antara lain: lingkungan pesantren (mayoritas masyarakat santri), bidang perdagangan, pertanian, perbengkelan. Dalam hal ini SMP Ibrahimy 2 Sukorejo sudah mencoba degan beberapa program pendukungnya, di antaranya adalah BMK (Bimbingan Membaca Kitab), BMQ (Bimbingan Membaca Quran), MTK Club, Inggris Club, Basket, Sepak Bola, Bola Voli, Paduan Suara, Paskibra, PMR, Zaven Club, Batik. Khusus untuk BMK dan BMQ memang merupakan program unggulan. Bahkan, untuk menyeleksi siswa untuk mengikuti UN, siswa-siswi diwajibkan lulus ujian baca kitab level Jurumiyah dan lulus ujian Baca Alquran dengan kriteria penilaian: fasih makharijul huruf, membaca Alquran dengan tajwid yang benar, dan hafal surah-surah pendek.

Kedua, Adanya kebutuhan, minat dan bakat peserta didik untuk mengikuti program yang ditetapkan oleh lembaga ini. Minat dan bakat peserta didik dapat dikembangkan melalui program unggulan sekolah yang terintegrasi dalam kurikulumnya. Di SMP Ibrahimy 2 Sukorejo kebutuhan minat dan bakat siswa benar-benar diperhatikan.

Ketiga, Adanya daya dukung/potensi pada satuan pendidikan (internal) yang meliputi:

a) Kurikulum Sekolah yang memuat program keunggulan lokal melalui integrasi pada mata pelajaran yang relevan atau melalui mata pelajaran muatan lokal dan/atau keterampilan.

b) Sarana prasarana: ruang belajar, peralatan praktik, media pembelajaran, buku/bahan ajar sesuai dengan program pendidikan. Di lembaga ini telah tersedia beberapa ruang kelas yang memadai untuk belajar. Mushalla sebagai tempat berjamaah salat duha, zuhur dan seminar, laboratorium IPA, laboratorium IPS, laboratorium komputer, internet, audio visual/multimedia (TV, LCD, OHP), ruang keterampilan/kesenian, ruang perpustakaan, ruang UKS.

c) Tenaga pengajar yang memiliki kemauan dan kemampuan untuk mengembangkan substansi materi pembelajaran dan sekaligus 
menerapkan dalam kegiatan pembelajaran, sesuai dengan mata pelajaran yang diampu. Tenaga pengajar dengan keahlian sesuai tuntutan/karakteristik program pendidikan. Dalam hal ini SMP Ibrahimy 2 Sukorejo sangat selektif dalam memilih tenaga pendidik, sehingga menghasilkan tenaga pendidik yang profesional dan kompeten di bidangnya.

d) Biaya operasional pendidikan. Adapun sumber biaya operasional pendidikan lembaga ini lebih banyak didukung dari swadaya mandiri dan masyrakat serta melalui berbagai sumber yang ada, baik dari donatur tetap, dermawan, simpatisan atau sponsorship yang tidak mengikat. Untuk biaya operasional harian, memanfaatkan dan mengelola SPP/UTAP dan iuran siswa. UTAP ini bukan dibebankan pada siswa, melainkan dialokasikan dari dana BOS.

e) Tersedianya tenaga pengajar yang kompeten di bidang keagamaan.

Kelebihan dari implementasi struktur integrasi kurikulum di lembaga ini di antaranya karena menerapkan model pendidikan terpadu mengenai kurikulumnya. Di sisi lain, ada beberapa kelemahan yang tidak bisa dipungkiri, antara lain: terlalu banyaknya materi yang harus dipelajari dan diserap oleh siswa. Hal ini akan menyebabkan beberapa kelelahan fisik maupun psikis yang dirasakan siswa, karena mereka juga mempunyai keterbatasan. Di samping itu, siswa harus dituntut untuk dapat menjaga keseimbangan kemampuan intelegen dan IQ-nya dengan apa yang diinginkan, apa yang dirasakan dan apa yang didapatkan. Idealisme lembaga untuk mencapai target kurikulum dan ingin mempertahankan status sebagai sekolah unggulan, kadang justru memberatkan siswanya. Untuk menyederhanakan pembahasan sub bab dalam penelitian ini, berikut ini bagannya: 


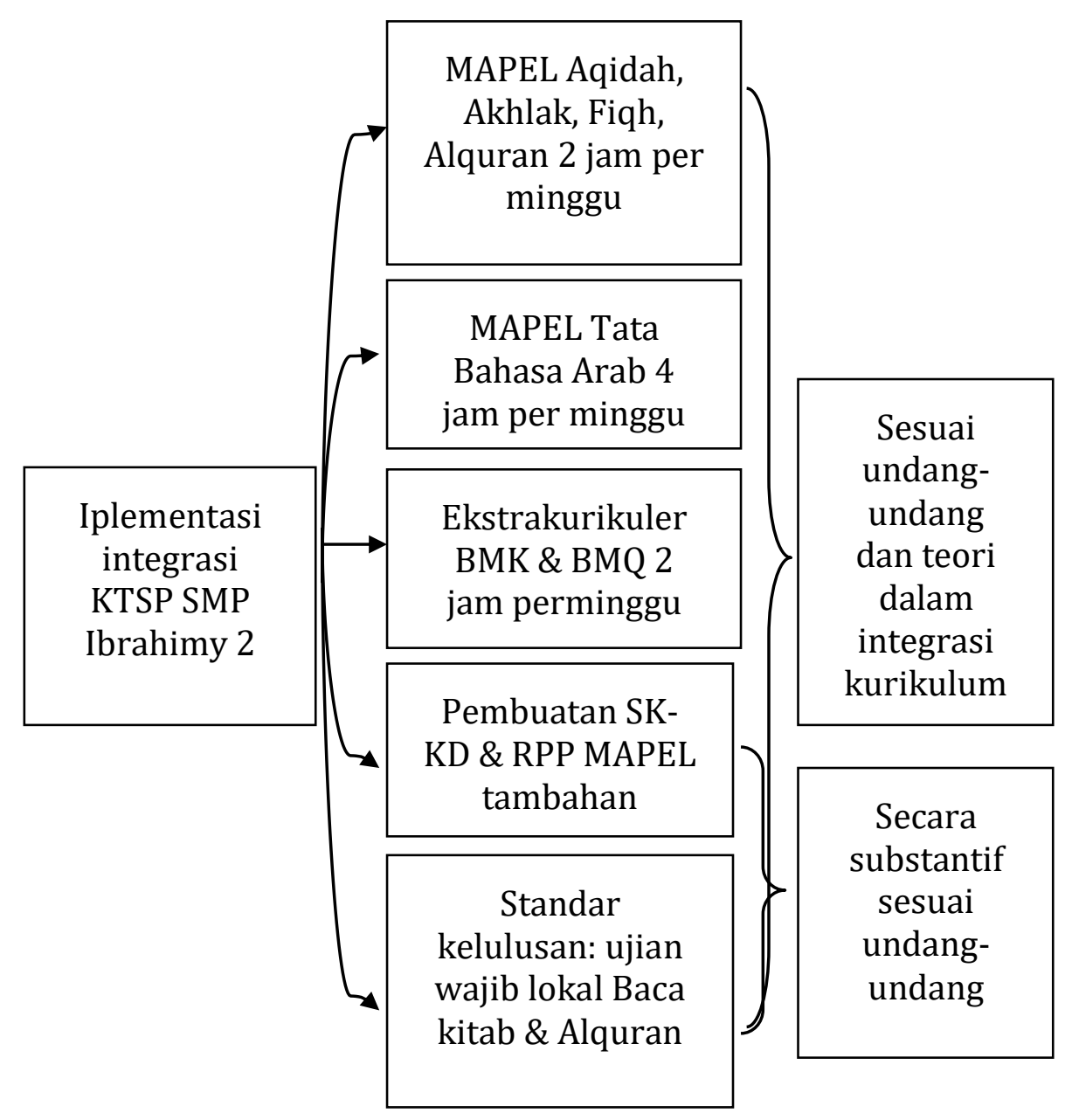

Bagan 5.2: Implementasi Struktur Integrasi KTSP dengan Kurikulum Pesantren di SMP Ibrahimy 2 Sukorejo Situbondo

\section{Indikator Keberhasilan Implementasi Integrasi Kurikulum Tingkat Satuan Pendidikan (KTSP) dengan Kurikulum Pesantren di SMP Ibrahimy 2 Sukorejo Situbondo}

Keberhasilan implementasi integrasi Kurikulum Tingkat Satuan Pendidikan (KTSP) yang diintegrasikan dengan kurikulum pesantren di SMP Ibrahimy 2 Sukorejo dapat dilihat dari kinerja guru, ketuntasan belajar, ketuntasan materi pelajaran, pencapaian prestasi akademik siswa, dan prestasi non-akademik. 
Beberapa keberhasilan implementasi integrasi kurikulum dapat dilihat dari pencapaian prestasi akademik siswa, yakni hasil Ujian Nasional (UN) dalam 9 tahun sebagai berikut: Matematika: $\geq 7$, Bahasa Indonesia: > 8, Bahasa Inggris: > 7, IPA: > 7. Dari hasil ini, maka tidak pernah ada kejadian ketidaklulusan siswa-siswi dalam UN. Selain prestasi di bidang akademik, keberhasilan implementasi integrasi kurikulum ini dapat dilihat dari prestasi non-akademik, yaitu berupa juara 2 lomba Qari' tingkat SMP se-Kab. Situbondo dan mewakili Situbondo di even lomba Qari' se-Jawa Timur.

Keberhasilan lainnya berupa kemampuan life skill yang dimiliki siswa. Hal ini dapat terbukti dengan kreatifitas hasil karya siswa yang selalu bermunculan dan dipamerkan pada setiap akhir semester. Setiap anak akan menghasilkan karya pada setiap skill yang dikuasai, seperti: lukisan, kaligrafi, kerajinan tangan, tata boga (ketrampilan memasak), basket, sepak bola, bola voli. Selain life skill dalam bidang umum ini, siswasiswi juga terampil dalam bidang-bidang keagamaan seperti dalam pembacaan barzanji, tahlil, dan pembiasaan dalam ibadah-ibadah sunnah. Hal ini tentu sesuai dengan tujuan KTSP SMP Ibrahimy 2, yaitu menyeimbangkan antara pengetahuan agama dan umum.

Untuk terus meningkatkan keberhasilan ini, Rapat evaluasi Kegiatan Belajar Mengajar (KBM) dilaksanakan 3 bulan sekali (middle semester). Evaluasi ini dilakukan oleh pimpinan sekolah dan seluruh guru. Tujuan dari evaluasi ini adalah untuk membahas sejauh mana target kurikulum yang sudah dicapai serta apa saja kendala yang ditemui. Dari beberapa kendala tersebut, maka akan dicarikan beberapa solusinya secara bersama-sama.

Selain indikasi keberhasilan yang dirasakan siswa-siswi, keberhasilan juga terlihat pada kekreatifan para guru dalam penyusunan materi MAPEL tambahan. Hal ini terbukti dari penyusunan buku panduan Tata Bahasa Arab yang memang disiapkan untuk MAPEL tersebut.

Demikianlah beberapa indikasi keberhasilan struktur integrasi KTSP di SMP Ibrahimy 2. Untuk menyederhanakannya, berikut ini bagannya.

$212 \mid$ JURNAL LISAN AL-HAL 


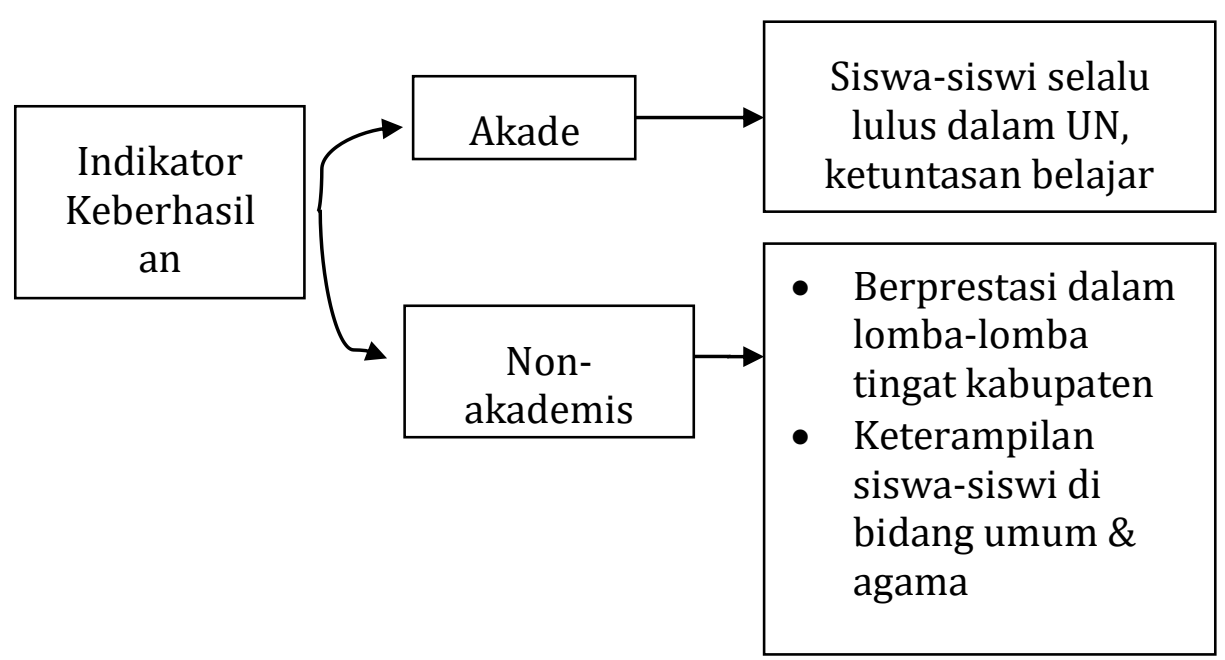

Bagan 5.3: Indikasi keberhasilan Struktur Integrasi KTSP dengan Kurikulum Pesantren di SMP Ibrahimy 2 Sukorejo Situbondo

Demikianlah tiga (3) pembahasan dalam penelitian ini yang merupakan gabungan antara paparan data dan temuan penelitian. Berikut ini tabel mengenai tiga pembahasan tersebut:

Tabel 5.1: Tabel Data dan Temuan Penelitian

\begin{tabular}{|c|c|c|}
\hline No. & JENIS DATA & TEMUAN LAPANGAN/PENELITIAN \\
\hline 1. & \begin{tabular}{lr} 
Struktur & Integrasi \\
Kurikulum & Tingkat \\
Satuan Pendidikan \\
(KTSP) & dengan \\
Kurikulum & \\
Pesantren di SMP \\
Ibrahimy 2 Sukorejo \\
\multicolumn{2}{l}{ Situbondo }
\end{tabular} & $\begin{array}{l}\text { a. Struktur integrasi kurikulum } \\
\text { KTSP SMP Ibrahimy } 2 \text { dilakukan } \\
\text { dengan memasukkan sebagian } \\
\text { kurikulum pesantren ke } \\
\text { kurikulum SMP Ibrahimy 2. } \\
\text { Sebagian kurikulum tersebut } \\
\text { yaitu dengan memasukkan } \\
\text { MAPEL Tata Bahasa Arab (Ilmu } \\
\text { Nahwu dan Sharraf), Fiqh, Aqidah, } \\
\text { dan Akhlak. } \\
\text { b. Tujuan integrasi ini adalah untuk } \\
\text { mendukung materi PAI dan untuk } \\
\text { menyeimbangkan antara } \\
\text { pengetahuan agama dan } \\
\text { pengetahuan umum. }\end{array}$ \\
\hline
\end{tabular}




\begin{tabular}{|c|c|c|}
\hline & & $\begin{array}{l}\text { Faktor yang melatarbelakangi } \\
\text { integrasi ini yaitu karena tuntutan } \\
\text { dari pesantren dan adanya } \\
\text { ketidakpuasan lembaga SMP } \\
\text { Ibrahimy } 2 \text { terhadap materi PAI } \\
\text { yang dinilai terlalu ringkas. }\end{array}$ \\
\hline 2. & $\begin{array}{l}\text { Implementasi } \\
\text { integrasi } \\
\text { Tingurikulum } \\
\text { Pendidikan } \quad \text { Satuan } \\
\text { dengan } \\
\text { dengan kurikulum } \\
\text { pesantren di SMP } \\
\text { Ibrahimy } 2 \text { Sukorejo } \\
\text { Situbondo }\end{array}$ & $\begin{array}{l}\text { a. Implementasi dalam Integrasi } \\
\text { KTSP SMP Ibrahimy } 2 \text { adalah } \\
\text { dengan memasukkan sebagian } \\
\text { MAPEL dalam kurikulum } \\
\text { pesantren. MAPEL tersebut } \\
\text { adalah Fiqh, Aqidah, Akhlak, } \\
\text { Alquran, dan Tata Bahasa Arab } \\
\text { (Nahwu \& Sharraf). } \\
\text { b. Untuk durasi waktu yang } \\
\text { disediakan pada MAPEL Fiqh, } \\
\text { Aqidah, Akhlak, Alquran adalah } 2 \\
\text { jam per minggu dengan pengajar } \\
\text { yang sama dengan pengajar PAI } \\
\text { yang notabene merupakan } \\
\text { kurikulum nasional. Program } \\
\text { BMQ (Bimbingan Membaca } \\
\text { Alquran) juga diterapkan dalam } \\
\text { pendalaman materi Alquran dan } \\
\text { jamnya dilaksanakan di jam-jam } \\
\text { ekstrakurikuler. } \\
\text { c. Untuk durasi waktu yang } \\
\text { disediakan pada MAPEL Tata } \\
\text { Bahasa Arab (Nahwu dan Sharraf) } \\
\text { adalah } 4 \text { jam per minggu dengan } \\
\text { pengajar lain. Untuk menunjang } \\
\text { MAPEL ini, diadakan program } \\
\text { BMK (Bimbingan Membaca Kitab). } \\
\text { d. Metode pembelajaran Tata Bahasa } \\
\text { Arab juga mengadopsi metode } \\
\text { dari pesantren, yaitu dengan } \\
\text { menerapkan metode ada' dan } \\
\text { sorogan. Tata Bahasa Arab dan } \\
\text { e. MAPEL Tata } \\
\text { Alquran harus benar-benar }\end{array}$ \\
\hline
\end{tabular}




\begin{tabular}{|c|c|c|}
\hline & & $\begin{array}{l}\text { dipahami secara mendalam oleh } \\
\text { para siswa-siswi, sebab sebelum } \\
\text { mengikuti ujian UN, diwajibkan } \\
\text { lulus ujian baca kitab dan lulus } \\
\text { ujian baca Alquran. } \\
\text { f. Tiap-tiap MAPEL tambahan } \\
\text { tersebut sudah dilengkapi dengan } \\
\text { SK-KD dan RPP dari masing- } \\
\text { masing MAPEL. Bahkan, pada } \\
\text { materi Tata Bahasa Arab (Nahwu } \\
\text { \& Sharraf) telah ada buku } \\
\text { panduannya yang diteritkan oleh } \\
\text { SMP Ibrahimy } 2 \text { sendiri. } \\
\text { g. Materi ke-NU-an yang notabene } \\
\text { merupakan MAPEL Wajib } \\
\text { pesantren tidak diintegrasikan, } \\
\text { sebab ajaran-ajaran dalam NU } \\
\text { sudah terakomodir dalam MAPEL } \\
\text { Fiqh, Aqidah, dan Akhlak. Selain } \\
\text { itu, keterbatasan waktu tidak } \\
\text { memungkinkan untuk } \\
\text { diadakannya materi ke-NU-an. } \\
\text { h. Implementasi integrasi kurikulum } \\
\text { ini tidak sampai mengganggu jam } \\
\text { pelajaran mata pelajaran lainnya. }\end{array}$ \\
\hline 3. & 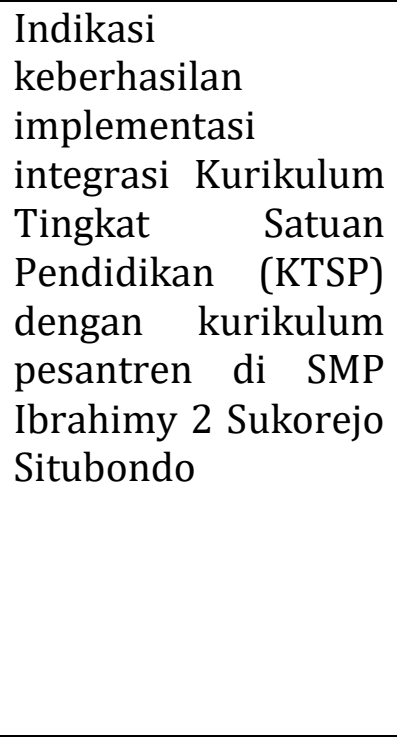 & $\begin{array}{l}\text { a. Indikasi keberhasilan dari } \\
\text { integrasi kurikulum ini banyak } \\
\text { macamnya, di antaranya: } \\
\text { ketuntasan belajar, ketuntasan } \\
\text { materi pelajaran, pencapaian } \\
\text { prestasi akademis dan non } \\
\text { akademis para siswa-siswinya. } \\
\text { b. Para dewan guru lebih kreatif } \\
\text { dengan menyusun buku panduan } \\
\text { MAPEL tambahan, berupa ilmu } \\
\text { Tata Bahasa Arab. } \\
\text { c. Dari sisi hasil UN (akademis), } \\
\text { selama kurikulum diintegrasikan, } \\
\text { tidak pernah ada siswa yang tidak } \\
\text { dalam mengikuti UN. Hal ini }\end{array}$ \\
\hline
\end{tabular}




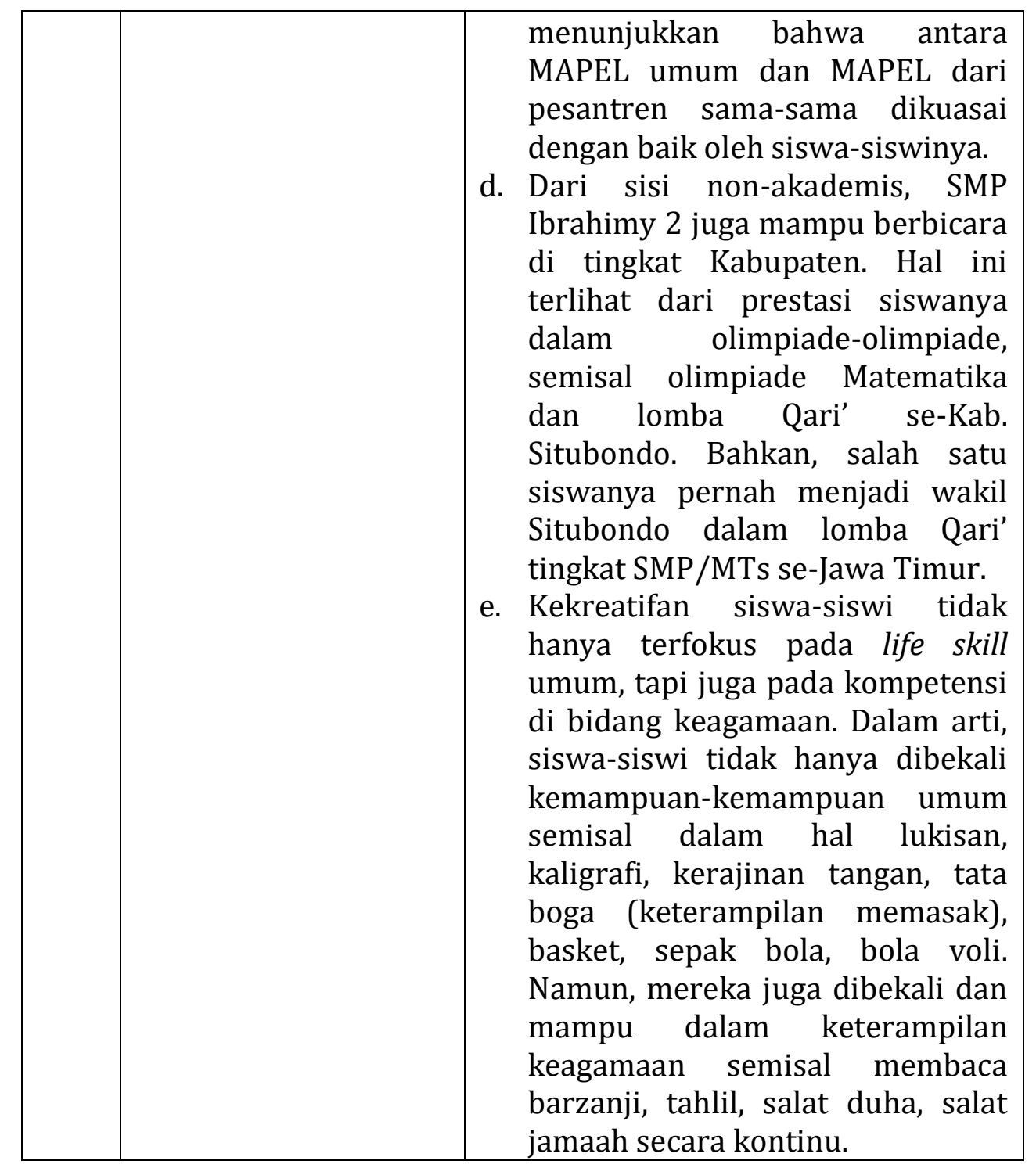

\section{Simpulan}

Struktur integrasi Kurikulum Tingkat Satuan Pendidikan (KTSP) di SMP Ibrahimy 2 Sukorejo Situbondo adalah bermula dari kewajiban pemberlakukan kurikulum pesantren/kurikulum lokal (kurlok). Kurlok tersebut yaitu MAPEL Aqidah, Fiqh, Akhlak, Alquran, dan Tata Bahasa Arab. Kewajiban ini akhirnya ditinjaklanjuti oleh SMP Ibrahimy 2 dengan memberlakukan KTSP integratif, yaitu dengan memadukan antara kurikulum nasional dengan kurikulum pesantren. Tujuan dari KTSP integratif ini adalah: 1) Untuk mendukung dan melengkapi materi PAI 
yang merupakan materi wajib kurikulum nasional. 2) Untuk menyeimbangkan antara ilmu umum dan ilmu keagamaan. Dengan demikian, aspek intelektual, emosional, sosial, dan moral keagamaan sudah terakomodir semuanya, sehingga standar bahan dan tujuan kurikulum nasional terpenuhi.

Implementasi KTSP integratif di SMP Ibrahimy 2 adalah dengan menetapkan beberapa standar, yaitu: 1) Memasukkan MAPEL Aqidah, Akhlak, Fiqh, dan Alquran sebagai mata pelajaran wajib dan masingmasing mendapat porsi 2 jam pelajaran per minggu. 2) Memasukkan MAPEL Tata Bahasa Arab dengan porsi waktu 4 jam pelajaran per minggu. 3) Ekstrakurikuler BMK dan BMQ yang merupakan materi pendukung untuk kurlok diberi porsi waktu 2 jam per minggu. 3) Para dewan guru kurlok diwajibkan membuat SK-KD dan RPP untuk masing-masing kurlok yang diintegrasikan. 5) Standar kelulusan disyaratkan harus lulus ujian kitab dan Alquran sebelum mengikuti UN (Ujian Nasional).

Keberhasilan implementasi integrasi Kurikulum Tingkat Satuan Pendidikan (KTSP) di SMP Ibrahimy 2 Sukorejo dapat dilihat dari beberapa hal: 1) Kinerja guru yang terlaksana, yaitu eksistensi para guru dalam pembuatan SK-KD, RPP, silabus dan buku panduan kurlok. 2) Ketuntasan belajar, yaitu siswa-siswi SMP Ibrahimy 2 selalu lulus ujian sekolah dengan standar lulus ujian sekolah di atas 70. 3) Ketuntasan materi pelajaran, yaitu setiap MAPEL diajarkan secara tuntas oleh para guru. 4) Pencapaian prestasi akademik siswa, yakni hasil Ujian Nasional (UN) dalam 9 tahun sebagai berikut: Matematika: $\geq 7$, Bahasa Indonesia: > 8, Bahasa Inggris: > 7, IPA: > 7. Dari hasil ini, maka tidak pernah ada kejadian ketidaklulusan siswa-siswi dalam UN. 5) Prestasi non-akademik, yaitu berupa juara 2 lomba Qari' tingkat SMP se-Kab. Situbondo dan mewakili Situbondo di even lomba Qari' se-Jawa Timur. Keberhasilan non akademis lainnya berupa kemampuan life skill yang berupa kreatifitas hasil karya siswa yang selalu bermunculan dan dipamerkan pada setiap akhir semester dan keterampilan keagamaan.

\section{DAFTAR PUSTAKA}

A. Hamid Syarif, Pengembangan Kurikulum, Surabaya: PT Bina Ilmu, 1996. Adi W. Gunawan, Genius Learning Strategy, Jakarta: PT. Gramedia Pustaka Utama, 2004.

Amhasan,"Pengembangan Profesionalisme", http://artikel.US/amhasan. html. 20 Maret 2007.

Bernand Berelson dan Carry Steiner, Human Behavior an Interview of 
Scientific Findings, New York Brase \& Word Inc, 1964.

BSNP, Panduan Penyusunan KTSP Jenjang Pendidikan Dasar dan Menengah, tt: tp., 2006.

Hasan Langgulung, Manusia dan Pendidikan: Suatu Analisa Psikologik dan Pendidikan, Jakarta: Pustaka al-Husna, 1989.

Hendyat Soetopo dan Wasty Soemanto, Pembinaan dan Pengembangan Kurikulum, Jakarta: Bumi Aksara, 1993.

J. J. Pasaribu dan B. Simanjuntak, Proses Belajar Mengajar, Bandung: Tarsito, 1980.

Kunandar, Guru Profesional, Jakarta: Raja Grafindo Persada, 2007.

Luqman Hakim, Kapita Selekta Pondok Pesantren, Tradisi Pendidikan Pesantren, Jakarta: Depag RI, 2002.

Masnur Muslich, KTSP Dasar Pemahaman dan Pengembangannya, Jakarta: Bumi Aksara, 2007.

Mauritz Johson, Internationality in Education, New York: Center for Curriculum Research and Services, 1967.

Mulyasa, Kurikulum, Jakarta: Raja Grafindo Persada, 2008.

Nana Sudjana, Pembinaan dan Pengembangan Kurikulum di Sekolah, Jakarta: Sinar Baru Algensindo, 2005.

Nana Syaodih Sukmadinata, Pengembangan Kurikulum Teori dan Praktik, Bandung: Remaja Rosdakarya, 2000.

Suryobroto, Proses Belajar-Mengajar di Sekolah, Jakarta: Rineka Cipta, 1997.

218 JURNAL LISAN AL-HAL 